Journal of Social Sciences 8 (2): 294-303, 2012

ISSN 1549-3652

(C) 2012 Science Publications

\title{
Students' Voices about Learning with Technology
}

\author{
${ }^{1}$ Ruth Geer and ${ }^{2}$ Trudy-Ann Sweeney \\ ${ }^{1}$ Division of Education, Arts and Social Sciences, School of Education, \\ University of South Australia, Adelaide, South Australia \\ ${ }^{2}$ Faculty of Education, Humanities and Law, School of Education, \\ Flinders University, Adelaide, South Australia
}

\begin{abstract}
Problem statement: This study argues for the inclusion of student voice as a valid means of identifying 21st century pedagogical approaches to learning. Today's students are increasingly living and thriving in a digital world and have a new "digital vernacular" which leads to differences in the way students think about learning. Approach: In Australia many students are already immersed in technologies and have preconceived ideas of what technologies they can expect to use in the classroom and how they will learn. Our schools are slowly changing but are struggling to understand what a contemporary learning environment might look like. Current and emerging technologies are forcing teachers to rethink how best to prepare students for the demands and challenges of the 21 st century. Results: Technology plays a key role in how students play, learn, gain information and interact with others. Teachers are challenged to find ways of tapping into the natural curiosities of students allowing them to do more learning on their own. This study explores the use of student voice in an Australian primary school as a valid method to inform teachers about what tools can best support students in their learning. Focus groups, questionnaires and drawings are used to identify technologies, strategies and settings that help students to learn. Conclusion: The findings indicate that students expect to use a variety of technologies in their learning as many students use technologies as a natural tool in their everyday life. This research attempts to clarify what a contemporary learning environment might look like and what teaching strategies and technologies can increase motivation and engagement thus improving student learning opportunities. The student data also includes suggestions to teachers on how they may provide rich learning experiences for students.
\end{abstract}

Key words: Information and Communication Technologies (ICT), Interactive Whiteboard (IWB), student voice, technologies, contemporary learning environment, student learning

\section{INTRODUCTION}

Today's students are very different. In Australia many students are growing up in a digital age where they have constant exposure to a variety of media that is impacting on the way they interact and use information (Jukes and Dosaj, 2006). Proficiency in the use of Information and Communication Technologies (ICT) are considered essential prerequisites for participation in society and the workforce. Students are entering our classrooms with certain preconceived ideas about how they want to learn and the tools that they will use to support their learning. Teachers frequently underestimate their students' ability to be perceptive about what works for them and what does not work (Thiessen and CookSather, 2007). In exploring how technologies can be most effectively integrated into classroom learning it is important to acknowledge that not all students have the same digital exposure where they have access to the latest technologies on a regular basis. However, what we do know is that these students have different lives from previous generations, as many parents work and students are left more to their own devices.

Such dramatic advances in technology have brought about changes in life style with students having increased communication options and exposure to vast quantities of information. Today's world is far more visual with simultaneous texts, images and sounds. Students have increased opportunities to interact with their peers and their environment as well as multitask with the tools afforded through the social web. Although educators have for years carried out 


\section{J. Social Sci., 8 (2): 294-303, 2012}

extensive research on how students learn and what strategies should be used in the classrooms, not all this research has been widely accepted. There is still much debate about whether Gen $\mathrm{Z}$ and possibly also Gen Y students can be referred to as 'digital natives' (Bennett et al., 2008). There has always been variety in our classrooms, in the learning abilities of students, in their cultural backgrounds, in their learning preferences and in their general interests. In the same way there are differences amongst those referred to as 'digital natives'. What is known however is that different strategies and technologies are needed if we wish to engage students in meaningful learning?

Currently new technologies are giving students a voice and an audience in the online world. Although it would generally be agreed that schools exist for the purpose of educating students, students are rarely involved in the democratic decision making processes of bringing about reform. This study argues for the inclusion of student voice as a valid method that can benefit both students and teachers in identifying pedagogical changes that can enhance the learning of students. As technologies are constantly emerging students can make a significant contribution by informing which technologies support their learning and what contemporary learning environments should look like. As teachers, we prepare students to problem solve, think critically and make ethical decisions. We empower them to have a voice, yet they have no meaningful voice in their own learning (Prensky, 2005). Thus, as teachers of the 21st century, it is important that we include students in decisions about what, where and how they learn while also negotiating authentic and rich assessment tasks. "To improve student achievement, it makes sense to go straight to the source-students" (Mitra, 2008)

This study forms part of a larger 3 year longitudinal ICT project. It attempts to give students a voice that will inform teachers about what tools and strategies can best support them in their learning. A case study approach is used to unpack what a contemporary learning environment might look like. As is the case with adults, students do not have just one voice but differ in their experiences, opinions and modes of expression (Hargreaves et al., 2010). Therefore a variety of methods are used to collect data from Reception ( 5 year olds) to Year 7 (13 year olds) in a government primary school in South Australia. Students were asked to draw a picture of the things that helped them learn. The visual representations of tools that helped students learn and the accompanying comments of how they supported their learning were examined to identify what a contemporary learning environment might look like from their perspective.
Other data collection methods included responses from questionnaires and from a number of focus groups on what technologies they liked to use as well as skills and strategies that would make learning meaningful and engaging. By using a variety of methods the researchers were able to gain a more accurate picture of the technologies that students regard as supportive of their learning.

Background: Information and communication technologies are essential tools in today's world. The use of ICT provides opportunity for students to learn in multiple ways and in multiple spaces (Robertson et al., 2004). Students have indicated that ICT can make learning fun and enjoyable which might suggest more on-task behavior and better conceptual understanding. In a report on the value of technology for learning, Davies et al. (2008) identified that technology does have an impact on student engagement in learning. In addition, $60 \%$ of teachers reported that it better supported learners' diverse needs. Condie et al. (2007) also found that, when students utilized ICT in their learning, increased motivation and a high level of engagement was evident. Combined with other variables such as student independence, deeper understanding and higher order thinking, increased motivation may lead to improved achievement.

Although vast amounts of money have been spent on the purchase of technologies (mainly computers), our education system is struggling to bridge the gap between how students live their lives and how they are expected to learn in schools. In general, students have access to a wide range of digital technologies which are often more current and less restrictive than the technologies at school. "They crave access to tools that let them network with peers or anyone else they choose to interact with" (Jukes and Dosaj, 2006). Students frequently find that when they enter the classroom they are limited in the way they use the technologies, which might be constrained either by the skills of their teacher, access in the classroom and currency of the technologies. Kent and Facer (2004), in their study on students' home and school use of ICT, suggest that "the school might act as a site of informal learning... and the home as a site of formal learning" (p. 452) as students have far better and less restrictive access at home. Such an idea challenges educators to think earnestly about how they might transform their classrooms to be engaging places of learning.

There is an increasing body of literature that argues for the validity of student voice as a strategy for school reform. Teachers need to "take seriously what students can tell us about their experience of being a learner in school- 


\section{J. Social Sci., 8 (2): 294-303, 2012}

about what gets in the way of their learning and what helps them to learn" (Rudduck and Flutter, 2004). At the same time when adopting the notion of listening, teachers also need to recognize that student voice is constrained by their experiences and background just as teachers are also limited by their understandings and knowledge. Fielding (2004) argues that the social setting and identity shape the way that both teachers and students view the world. Similarly language and also images are saturated with values. Despite these limitations student voice is important in seeking to personalize the learning and make it more meaningful for students.

In further arguing for the value of student voice, Stefi-Mabry et al. (2010) suggest that it is ironic that teachers insist on students learning from them, but they rarely take time to learn from students. This can be exasperated by the lack of knowledge about individual students and their lives. Cook-Sather (2006) discusses the importance of listening closely to what students have to say, while also acknowledging that silence can be powerful as it can mean that it is not worthwhile or safe to speak. Through building relationships with students, teachers will gain a greater understanding of how they learn and what they think about learning. Although learner autonomy and independent thinking is encouraged there may be a sense of mistrust of the views of students (Savin-Baden, 2003). Without taking time to listen and understand students, the implementation of what might be considered sound pedagogical practices may in fact not engage students in the process. There is the danger that the learning may be more relevant to the teacher than the student (Jukes and Dosaj, 2006) as there can be a difference between how teachers think and how students think, as well as how they learn. When considering an educational change, the focus must always be on student learning.

Research is increasingly providing evidence that technology is impacting positively on student learning outcomes (Davies et al., 2008; Condie et al., 2007). Cox et al. (2004) goes further in concluding that teachers' pedagogies, where technologies are appropriately chosen and effectively integrated, have a positive impact on student achievement. They suggest that the most effective use is where ICT are closely linked to curriculum objectives and are regular components of the classroom experience. Robertson et al. (2004) recommend that the pedagogy must be authentic which situates the learning within the students' everyday lives and their personal context. There is an emerging research interest in investigating student opinions. The use of student voice as a means of informing educational change can be grounded in a theoretical framework of constructivism, critical constructivism, critical pedagogy and the notion of listening to students -student voice (Stefi-Mabry et al.,
2010). Such theories underpin our understandings about how students build knowledge and the constructs under which they learn.

Constructivist learning theories support the belief that students learn by actively constructing their own knowledge through building on previous knowledge and synthesizing it with new understandings. Prior knowledge is considered important in our contemporary understanding of learning which suggests that prior knowledge about our students is also important to ensure relevance and an active approach to learning. Critical constructivism which is built on constructivist beliefs argues that the role of schooling is to engage students in the knowledge production process which involves engaging students in analyzing, interpreting and building knowledge from diverse sources (Kincheloe, 2005). It also acknowledges that students come from diverse backgrounds and thus perceive their world in different ways supporting the view that student identities are important (Kincheloe, 2005). Teachers need to gain a greater understanding of their students by building relationships with them which will provide some insight into their learning and communication practices. Critical pedagogy, primarily based on the study of Paulo Freire, encourages students to think critically about their education situation. It is also grounded in the belief that every person deserves an education and thus need to be given the skills that will allow them to contribute as valued members of society while also improving them. Students are encouraged to rethink their understanding of the learning experience and their relationship with their teacher (Kincheloe, 2005). Such theories support the notion that students are key to their own learning. Thus, legitimising student perceptions and opinions gives credence to the use of student voice as a valid method for informing educational reform.

The study: This study reports on data collected from students about their learning in a metropolitan primary school in South Australia. The school has an enrolment of approximately 460 students ranging from Reception (5 year olds) to Year 7 (13 year olds) whose backgrounds tend to be middle class with $52 \%$ coming from non-English speaking backgrounds. About $90 \%$ of students have access to a computer at home with increasing access at school.

Visual representations: A number of methods were used to collect student data about what helped them to learn. One method required students to draw a picture of themselves with the various things that helped them to learn and to comment on how they used them. It was hoped that in asking students to visually represent an ideal learning environment that this might encourage 


\section{J. Social Sci., 8 (2): 294-303, 2012}

more individual and free expression without the limitations of language which may be an issue for younger students. It would also allow for the identification of multiple tools. More traditional methods of data collection are often constrained by the type of questions and the way they are asked and interpreted by students. Also in focus groups young children will often agree with each other and gleaning individual responses can be difficult. At the same time it was recognised that their drawings are limited by their experiences, backgrounds and also teachers' influences and approaches. Students were given 30 minutes in which to draw their picture and provide an explanation of their drawing, if possible. It was hoped that such drawings would add breadth and depth to the data collected using questionnaires and focus groups.

The drawings of 347 students were examined and the various resources identified in the drawings were recorded under a number of categories which included:

- New technologies: such as computers, laptops, the interactive whiteboard, bee-bots and educational games

- Old technologies: such as pencils, books, TV, clocks

- Persons: such as teacher, parents, family and friends

- Physical setting: such as furniture (round tables) library, environmental factors (sunlight)

- Activities: such as exercise, sport, excursions

- $\quad$ Personal aspects: such as brain, eyes, ears, food, drink

- Learning preferences: such as group work, posters and success criteria

Overall, 67 different items were identified by the students which suggested that students differ in their preferences and the way they liked to learn. Students varied in their approaches with some opting to create an ideal classroom, while others drew their existing classroom but with the tools that they would like to use in their classrooms. Some students also included other aspects such as the senses, food and environmental aspects that might contribute to optimum conditions for focused and effective learning. The 10 most popular items identified from all the drawings are listed in the Table 1.

Table 1: Things that helped students learn

\begin{tabular}{lrrrrrrrrrr}
\hline Year & Rec. Yr1 & \multicolumn{1}{c}{ Yr2 } & Yr3 & Yr4 & Yr5 & Yr6 & Yr7 & Total (\%) \\
\hline Student numbers & 51 & 47 & 41 & 36 & 40 & 28 & 52 & 52 & 347 & \\
Computers/Laptop & 26 & 31 & 24 & 21 & 36 & 28 & 48 & 52 & 266 & 77 \\
IWB & 13 & 25 & 9 & 11 & 9 & 21 & 40 & 24 & 152 & 44 \\
Dictionary & 12 & 19 & 10 & 13 & 17 & 6 & 22 & 22 & 121 & 35 \\
Books & 30 & 21 & 4 & 1 & 21 & 15 & 15 & 13 & 120 & 35 \\
Teacher & 5 & 9 & 7 & 6 & 7 & 5 & 13 & 14 & 66 & 19 \\
Parents/Family & 3 & 3 & 7 & 6 & 2 & 3 & 3 & 19 & 46 & 13 \\
Friends & 0 & 1 & 5 & 10 & 1 & 0 & 8 & 17 & 42 & 12 \\
Library & 0 & 2 & 8 & 2 & 2 & 12 & 2 & 9 & 37 & 11 \\
Calculator & 2 & 18 & 3 & 3 & 0 & 0 & 0 & 3 & 31 & 9 \\
Pencils & 5 & 24 & 0 & 0 & 0 & 0 & 0 & 0 & 29 & 8 \\
\hline & & & & & & & & & &
\end{tabular}

Across the year levels, computers were identified as the most popular tool that helped students learn. As all the classrooms had an Interactive Whiteboard (IWB) these were also identified by $44 \%$ of the students as useful tools. It is also interesting that books and dictionaries were considered as more useful than some of the other ICT tools. Such comments included: "books help me learn because I know it's true if it is in the nonfiction section"; "the dictionary helps me learn because they have lots of words". Family and friends but especially the teacher was recognised as important to the learning process. "The teacher helps us by explaining things". Further comments illustrated the importance of having access to a variety of tools that might serve different purposes:

"I find technology helpful because it has many uses and can be a good way to share work. Success posters motivate me throughout the day. Natural light stops me from getting headaches. I can focus better. When my friends explain the study sometimes I understand it better? (Year 7 student)".

"Laptops, information books, success criteria and feedback from the teacher help me to learn because on the internet I find useful info for projects and assignments. Info books help me to get information; study success criteria helps me because it gives me an idea of how to present my work; and feedback also helps me because when I get feedback it helps me improve my study if needed? (Year 6 student)".

"The internet helps me to find out about stuff. The pencil helps to write the stuff about what you find out. The ruler helps to draw. The rubber helps to get rid of that stuff. The teacher helps you learn and the brain helps you think about that stuff? (Year 3 student)".

The following two student drawings help to illustrate the things that they believe, helped them to learn.

The Year 7 student (Fig. 1) suggests in her drawing, that there is not one tool in particular that helps her learn but the combination of many tools, as some tools are better for one task and other tools are better at helping her to find the answer to other queries. However, she identifies the advantage of technologies being constantly updated which may provide additional support for students in their learning. 
Year:...7........

Male: $\square$

Female: $\llbracket$

Draw a picture of yourself with the things that help you learn.

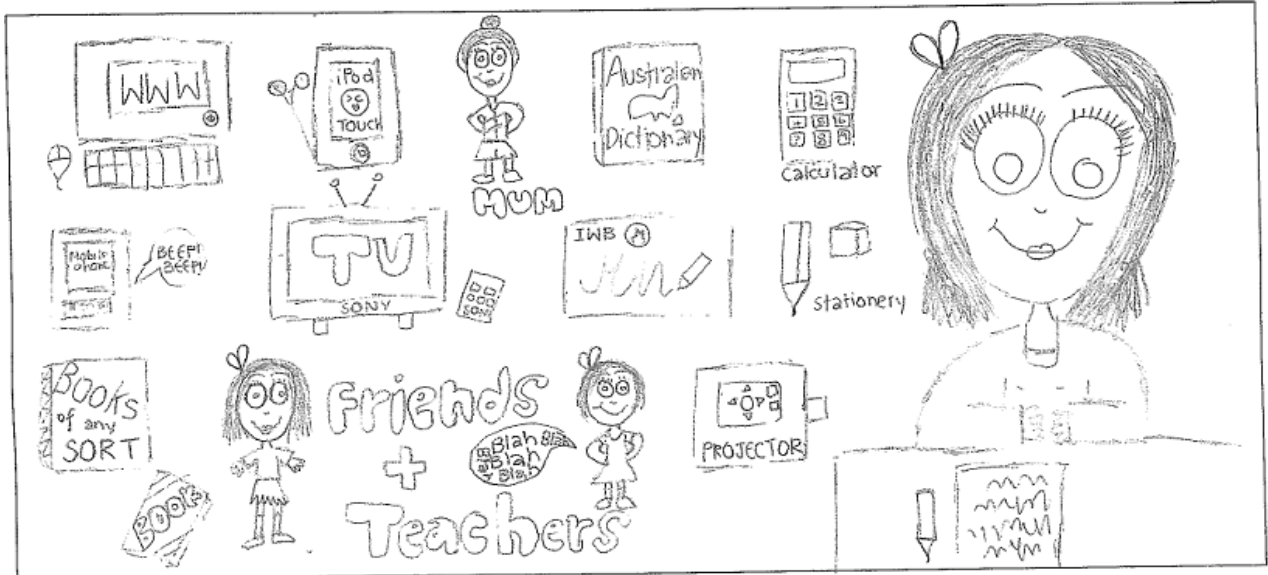

How did these things help you to learn?

They all have different ways of teaching me something. I really like the variety because if one of the objects don't give you the answer, you can try something else. Technology is great because its always updated.

Fig. 1: Year 7 student drawing of what helps her learn

$$
\text { Year:............. Male: } \square \quad \text { Female: } \square
$$

Draw a picture of yourself with the things that help you learn.

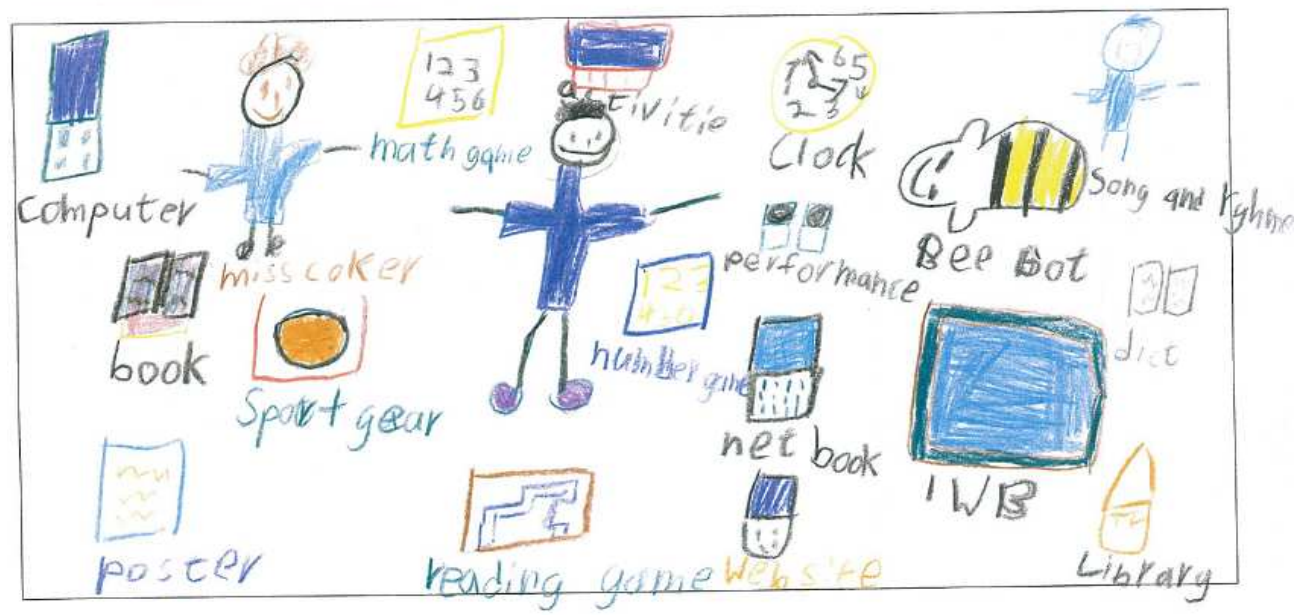

Fig. 2: Year 1 Student drawing of what helps him learn

The Year 1 student (Fig. 2) shows that a wide variety of technologies, tools and people help him to learn. This suggests there are many resources that students expect to have access to that will help them to learn while also maintaining a healthy life style.

Questionnaire: A survey was given to Years 6 and 7 students in 2009 and 2010 with over 100 students responding each year to questions about their learning and the impact of ICT. In 2009, they were asked what advice they would give to teachers to help them with their learning. Their responses fell under four themes which included: Explicit explanations, clarification and feedback, catering for individual needs and strategies for improving the lessons. An example of some of the comments by students is summarised in Table 2. 
Table 2: Student advice to teachers

\begin{tabular}{|c|c|c|c|}
\hline Explicit explanations & Clarification and feedback & Cater for individual needs & Lesson suggestions \\
\hline $\begin{array}{l}\text {-do the tasks with the } \\
\text { students to help them } \\
\text { understand the task. }\end{array}$ & $\begin{array}{l}\text {-personally talk to people and } \\
\text { give advice and don't just talk } \\
\text { in general. }\end{array}$ & $\begin{array}{l}\text {-the advice for teachers that } \\
\text { I would give is to make sure } \\
\text { you cater for every student's } \\
\text { needs. }\end{array}$ & $\begin{array}{l}\text {-to let us sit where we want or to } \\
\text { let us talk for a little bit between } \\
\text { lessons so we can discuss what } \\
\text { we are doing unless it is an }\end{array}$ \\
\hline $\begin{array}{l}\text {-explain things better and } \\
\text { give me more examples. }\end{array}$ & $\begin{array}{l}\text {-it would be good if teachers } \\
\text { went around and asked }\end{array}$ & $\begin{array}{l}\text {-more challenging ICT } \\
\text { tasks, what we have already }\end{array}$ & $\begin{array}{l}\text { individual project. also to let us } \\
\text { be ourselves. }\end{array}$ \\
\hline $\begin{array}{l}\text {-always encourage your } \\
\text { students and explain } \\
\text { things properly. }\end{array}$ & $\begin{array}{l}\text { students if they understand the } \\
\text { lesson and if they don't then } \\
\text { sit down and explain the task. }\end{array}$ & $\begin{array}{l}\text { is too easy for me. We need } \\
\text { harder tasks for more } \\
\text { advanced users (like me :)) }\end{array}$ & $\begin{array}{l}\text {-make learning fun, like add } \\
\text { things that people like in to the } \\
\text { lesson. } \\
\text {-let us work in groups. }\end{array}$ \\
\hline $\begin{array}{l}\text {-my advice is to explain } \\
\text { things very well and don't }\end{array}$ & $\begin{array}{l}\text {-make sure to ask the children } \\
\text { "do you get it?" }\end{array}$ & $\begin{array}{l}\text {-talk to people more } \\
\text { individually. do more hands } \\
\text { on things. }\end{array}$ & $\begin{array}{l}\text {-students having a say in } \\
\text { what they do. }\end{array}$ \\
\hline $\begin{array}{l}\text { be mad if a student asks a } \\
\text { question even if you just }\end{array}$ & $\begin{array}{l}\text {-a bit more clearer in your } \\
\text { talking and also to give more } \\
\text { Feedback }\end{array}$ & -let them talk to you more as & -give us more time on the web. \\
\hline $\begin{array}{l}\text {-tell everyone lots of ways } \\
\text { to do the task. }\end{array}$ & $\begin{array}{l}\text {-you could help me with the } \\
\text { work I am troubled on. }\end{array}$ & & \\
\hline
\end{tabular}

Table 3: The impact of ICT on learning

\begin{tabular}{|c|c|c|c|}
\hline Interactive Whiteboards & Laptops/computers & The Internet as a resource & Other technologies \\
\hline $\begin{array}{l}\text {-it has had a massive } \\
\text { impact, it's a lot easier to } \\
\text { understand when using a } \\
\text { project/interactive white } \\
\text { board and it's always easy } \\
\text { to see. }\end{array}$ & $\begin{array}{l}\text {-we have a lot of laptops } \\
\text { and computers throughout } \\
\text { our school. It has allowed } \\
\text { me to complete work to } \\
\text { a higher, more organized } \\
\text { standard. }\end{array}$ & $\begin{array}{l}\text {-we can also write on our } \\
\text { blogs instead of writing our } \\
\text { reflections in a book. }\end{array}$ & $\begin{array}{l}\text {-my ICT teacher isn't very } \\
\text { helpful so I don't really } \\
\text { learn anything from him. }\end{array}$ \\
\hline $\begin{array}{l}\text {-this has allowed the } \\
\text { teachers to show stuff that } \\
\text { we wouldn't usually be } \\
\text { able to see. }\end{array}$ & $\begin{array}{l}\text {-when there is something } \\
\text { that } i \text { am not sure with } i \text { can } \\
\text { go on the computer and } \\
\text { check. }\end{array}$ & $\begin{array}{l}\text {-the computer is a great } \\
\text { resource to have in the } \\
\text { classroom. Soon books will } \\
\text { not be used for our work } \\
\text { and we will be using the } \\
\text { computers. }\end{array}$ & $\begin{array}{l}\text { However my local } \\
\text { computer nerd is really } \\
\text { helpful: he taught me how } \\
\text { to use Audacity, } \\
\text { Moviemaker and Publisher } \\
\text { when my ICT teacher }\end{array}$ \\
\hline $\begin{array}{l}\text {-interactive whiteboards } \\
\text { have helped me to }\end{array}$ & $\begin{array}{l}\text {-it has helped me in } \\
\text { different ways in my }\end{array}$ & $\begin{array}{l}\text {-I think that ICT has really } \\
\text { helped me because it }\end{array}$ & wouldn't help \\
\hline $\begin{array}{l}\text { understand things as the } \\
\text { teacher can show us what } \\
\text { we need to do on the } \\
\text { laptops and in our books. }\end{array}$ & $\begin{array}{l}\text { learning. I believe that I } \\
\text { have done some high } \\
\text { quality work while using } \\
\text { the laptops. }\end{array}$ & $\begin{array}{l}\text { makes learning more } \\
\text { interesting and gives me } \\
\text { more variety of resources. }\end{array}$ & $\begin{array}{l}\text {-it has had a good impact } \\
\text { because I am learning how } \\
\text { to use different programs } \\
\text { and being able to surf the net. }\end{array}$ \\
\hline $\begin{array}{l}\text {-it is clearer to understand } \\
\text { things because I can see } \\
\text { things being explained. }\end{array}$ & $\begin{array}{l}\text {-I remember things better } \\
\text { and the lessons on the } \\
\text { laptop are more enjoyable. }\end{array}$ & $\begin{array}{l}\text {-by having computers } \\
\text { involved in my learning it } \\
\text { has helped me to find more } \\
\text { quality information for } \\
\text { projects and things like that. }\end{array}$ & $\begin{array}{l}\text {-the impact that it has had } \\
\text { on me I've learnt how to } \\
\text { scan pictures on the } \\
\text { computer and do } \\
\text { Claymation. }\end{array}$ \\
\hline $\begin{array}{l}\text {-I believe that ICTs (such } \\
\text { as laptops and interactive } \\
\text { whiteboards) have } \\
\text { completely revolutionized }\end{array}$ & $\begin{array}{l}\text { - I think that using the } \\
\text { laptops has made learning } \\
\text { easier, fun and exciting. }\end{array}$ & $\begin{array}{l}\text {-using ICTs in the classroom } \\
\text { has had both good and bad } \\
\text { effect on my learning. }\end{array}$ & $\begin{array}{l}\text {-this has impacted my } \\
\text { learning by if I am } \\
\text { struggling in maths I can }\end{array}$ \\
\hline $\begin{array}{l}\text { the way that me and my } \\
\text { classmates learn. }\end{array}$ & $\begin{array}{l}\text {-the computers made } \\
\text { finding information a lot } \\
\text { faster and helped us get are } \\
\text { assignments done on time. }\end{array}$ & $\begin{array}{l}\text { Good because it can } \\
\text { provide me with quick answers } \\
\text { and a way to make my work } \\
\text { neater, nicer and look like } \\
\text { I have put in more effort. }\end{array}$ & go on a maths website. \\
\hline
\end{tabular}

In the 2010 questionnaire, students were also asked to comment on what impact ICT had had on their learning. Their comments (Table 3) tended to focus on positive benefits for them and have been categorised under a number of themes: such as the interactive whiteboard, laptops, the Internet and other technologies. Some key messages from these comments suggest that technologies can make concepts easier to understand, more enjoyable, more professional looking as well as providing an incredible resource by way of the Internet. Year 4-7 students were asked about what they valued in their learning and chose from a list of 21 items, collated from responses from student focus groups held 
across a number of schools in the project. The most common items identified were:

\section{Teachers explained things well}

My teachers encouraged me to achieve

My teachers provided useful feedback

The statement relating to teachers' use of ICT surprisingly, did not feature in the top 10 most selected items. This suggests that the students considered good teaching strategies as critical to their learning as the resources that they had at their disposal.

Focus groups: In addition, six student focus groups across the various year levels were held to gain further clarification on how computers were being used and how they were supporting their learning. The younger students particularly liked playing games that helped them with their numeracy and literacy skills. In particular, they liked the use of animation, audio and feedback. One Reception student commented:

"I like the cat game where there is an orange and a black cat [on a number line] ... and you have to choose the right number [if you add up both numbers] ... if you get it right the cat says 'Purrrrfect!'”

Both the year $1 / 2$ and year 2 student focus groups explained that they liked the interactivity of the IWB and when the teacher demonstrated what to do. One student commented:

"We can move around and use the pen on the IWB; on the computer you just sit there and type. The interactive whiteboard makes it easier to see [as a whole class] (unlike a computer monitor) and the teacher can show you what you need to do".

Similarly, the middle primary school students explained that they liked it when the teacher used the IWB to "show us what to do when we have the laptops". The students also added that it was also helpful when the teacher shared the IWB files because then "there is no need to copy down notes".

These students described a strong connection between the uses of the technology as tools to support clear learning intentions related to inquiry learning projects. They spoke about how they enjoyed "challenging tasks" where they had the opportunity to create an original product that required 'persistence' (one of the school's five keys to success).

For example, the group enthusiastically explained how they were currently using the Internet to research questions about how to save specific endangered animals of their choice and their plans to take photos for their individual presentations of their findings whilst on their forthcoming overnight "Zoo Snooze". Another example was when they created short videos using PhotoStory and Clay Animation using their own images and props. This group stated:

"We need technology as some things can't be done in books- like multimedia. ... If I make a mistake in writing in my book I would waste valuable learning time trying to rub it out but on the computer I can easily edit it.... I see a red line if I have a spelling mistake and a green line if there is a problem in a sentence. ... The suggested spellings help us to learn the correct spelling of words".

Interestingly, one student commented that they "wouldn't want to use a laptop all of the time as they would be glued to it and their handwriting would become wonky!"

The older primary students spoke more about the opportunities for communication and sharing of ideas afforded by the Internet. They claimed that it was important for them to learn how to use technology, as it is an important part of living in the 21 st Century. "We have laptops, not stone to carve!" Blogging was popular as it enabled them to keep a record of their learning as well as share their learning with their parents. The students also found it valuable when the teacher shared recommended websites via the class blog and the social bookmarking website (del.icio.us). One student commented:

"It's easy to keep in touch with friends using my school email account as I can use it from home and school ... and it doesn't use up phone credit. Email is a really good way to share our study with teachers and receive feedback before the due date. That way, we can get a better mark".

Students also highlighted that "the technology helps me with my leaning as it keeps it exciting, new and interesting. You are always wondering what you are going to do next. I get excited about using the laptop". Another student pointed out: 


\section{J. Social Sci., 8 (2): 294-303, 2012}

"For me, I have the handwriting style of a first grader so it helps me to improve my writing by making it neater and easier for the teacher to read. Normally, when I write, I rush to finish but if I am typing, it helps me to slow down and re-reading my study is easier".

\section{DISCUSSION}

This study uses the notion of student voice to represent data both visually and verbally. The drawings provided students with the opportunity for expression that was not necessarily dependent on their ability to articulate their thoughts. Although limited by the self-reporting nature of the responses, it did highlight the need to provide students with a variety of tools that will enable them to access, analyse and present information using a variety of media that are both challenging and enjoyable. It is also necessary to note that student experiences were to some extent limited by the context and culture of the school in which the data was collected and therefore may not be transferable to other educational settings.

Although the findings do not provide any new revelation on what helps students to learn it does suggest that the use of ICT does engage students and students do expect to use it for their learning. Students recognise such benefits as giving them ready access to a wealth of information for projects. They also believe that it makes learning more enjoyable and fun and also easier to produce professional looking and quality work. ICT also keeps them engaged in their study by using a variety of media to explain concepts and enhance their understanding. In addition, it supports greater collaboration between students. Students also requested more time to discuss their study with others as the use of ICT made it much easier to study collaboratively on projects.

Another aspect that was made clear particularly from the survey and focus group data was that the teacher was recognised as being important in the learning of the students. Teachers play an important role as a role model and in their design of meaningful learning tasks where ICT is used as a tool associated with clear learning objectives and student-centred and inquiry-based learning approaches. They saw the teacher as being the person who could explain difficult concepts, ensure that they understood the task, would cater for the individual needs of students and would use different strategies and media to aid this. The teacher was seen as the person to facilitate the learning, although the findings suggest that older students were less comfortable about the teacher's ability to use appropriate technologies. From the student questionnaires there was a sense that students were sometimes held back in their use of ICT because their teachers were not comfortable with the tool or they felt they firstly had to teach students the skills. Although the teacher did not feature predominantly in the drawings, it was assumed by many that the teacher would be involved in their learning. Many of the students understood the drawing activity as a medium for identifying tools that could help them learn, rather than the people.

Although large amounts of money have been spent on putting technology into the schools, limited resources are available for professional development for teachers. Jones (2004) in his review of the research literature identified a number of actual and perceived barriers to the uptake of ICT by teachers. One of the key determinants was the teachers' level of engagement with ICT and their level of confidence in using the technology. Other factors included the level of access to ICT and the appropriateness of the professional development in not only addressing the technical skills but also the pedagogical aspects related to effective ICT integration. Teachers' pedagogies have also been shown to affect students' achievements and are influenced by such factors as the type of technologies chosen, the ways they are utilized and the extent to which teachers plan and prepare for the integration (Cox et al., 2004).

From the data it has become obvious that students learn in different ways and therefore different tools and strategies are needed to equip students as citizens in the 21 st century. The teacher is critical in ensuring a mix that caters for the varying needs of students and in helping them to develop the higher order thinking skills that are needed to contribute to society. Although students in this study do like to use technologies, particularly those available to them at home, they recognised that other things are also important to their learning, such as a healthy lifestyle with a drink bottle to keep hydrated or brain food to help their concentration or more traditional tools such as a dictionary because they find it easier to look up the word or a pencil and exercise book because they want to quickly jot something down and transport it easily, or maintaining their handwriting capabilities. With students being active online participants even from an early age, there is a need to promote digital citizenship in schools to ensure that students understand their roles and responsibilities in digital society and are able to connect appropriately and safely with learning partners and resources that open possibilities for education (Ribble, 2011). 


\section{J. Social Sci., 8 (2): 294-303, 2012}

\section{CONCLUSION}

This data leaves educators with the challenge of seeking the holy grail of what an innovative contemporary learning environment might look like for today's students. As discussed earlier there is much research in trying to design and identify the cognitive skills and strategies required for the 21 st century classroom. Today's students are different, classrooms are more multicultural and the challenges faced by students, teachers and the school community have become more complex. The complicated lives of students outside of school has led to further challenges with students having increased independence resulting in augmented cyber-safety concerns. Although current research cannot directly claim that ICT has improved student outcomes we do know that there are decided benefits and that its effectiveness is very much dependent on the teacher having a sound pedagogical understanding of how technologies can be effectively employed to enhance student learning. In considering the list of tools that students consider important to their learning we also need to consider the school infrastructure in supporting the mix of tools as well as the professional development required to assist teachers in making the pedagogical shift. Required infrastructure and professional development opportunities will not happen without strong and committed school leaders who can identify how such complexities can be addressed within their varied school contexts.

Although there are no new insights from the data it has further given students a voice in assisting teachers to support them and better understand the tools that help kids learn. We know that students do not necessarily know what they do not know. This highlights the importance of the teacher in facilitating the learning and in helping them to acquire the skills and strategies needed to be successful in today's society. Students in general are drawn towards technologies as a motivational force that can assist their learning but they are not generally in the position to decide whether a particular technology is the most appropriate tool or how best to utilise it. From the data it can be concluded that technologies are only some of the many tools that can motivate, engage and enhance students in their learning. Other more traditional tools, the design of the physical space, the outside environment as well as teachers, friends and family all help students to be successful. There have always been compounding factors that help students learn but the increase in the availability of tools and other social, cultural and environmental factors require a multiplicity of tools in today's classroom. The challenge remains to explore and implement learning that identifies a 21 st learning environment without forgetting that a lot of learning does occur outside the classroom as well.

\section{REFERENCES}

Bennett, S., K. Maton and L. Kervin, 2008. The 'digital natives' debate: A critical review of the evidence. Br. J. Educ. Technol., 39: 775-786. DOI: 10.1111/j.1467-8535.2007.00793.x

Condie, R., B. Munro, L. Seagraves and S. Kenesson, 2007. The impact of ICT in schools-a landscape review. British Educational Communications and Technology Agency (BECTA).

Cook-Sather, A., 2006. "Change based on what students say": Preparing teachers for a paradoxical model of leadership. Int. J. Leadership Educ., 9: 345-358.

Cox, M., C. Abbott, M. Webb, B. Blakely, T. Beauchamp and V. Rhodes, 2004. A review of the research literature relating to ICT and attainment. London: British Educational Communications Technology Agency (Becta).

Davies, S., Steve and Pittard, 2008. Harnessing technology review 2008: The role of technology and its impact on education. Full report. British Educational Communications and Technology Agency (BECTA).

Fielding, M., 2004. Transformative approaches to student voice: Theoretical underpinnings, recalcitrant realities. Br. Educ. Res. J., 30: 295311.

Hargreaves, A., A. Lieberman and M. Fullan, 2010. Second International Handbook of Educational Change. 1st Edn., Springer, Berlin, ISBN: 9048126592, pp: 1077.

Jones, A., 2004. A review of the research literature on barriers to the uptake of ICT by teachers. BECTA ICT Research.

Jukes, I. and A. Dosaj, 2006. Understanding Digital Children (DKs): Teaching and learning in the new digital landscape. The InfoSavvy Group, Prepared for the Mass Teacher Lecture, Singapore.

Kent, N. and K. Facer, 2004. Different worlds? A comparison of young people's home and school ICT use. J. Compu. Assisted Learn., 20: 440-455. DOI: $10.1111 / \mathrm{j} .1365-2729.2004 .00102 . x$

Kincheloe, J.L., 2005. Critical Constructivism Primer. 1st Edn., Peter Lang, New York, ISBN: 0820476161, pp: 185.

Lindquist, J., 2010. What's the trouble with knowing students? Only time will tell. Pedagogy, 10: 175182. DOI: $10.1215 / 15314200-2009-030$ 
Mitra, D., 2008. Amplifying student voice. Educ. Leadership, 66: 242-251.

Prensky, M., 2005. Listen to the natives. Educ. Leadership 63: 8-13.

Ribble, M., 2011. Digital Citizenship in Schools. 2nd Edn., International Society for Technology in Education, Washington, D.C., ISBN: 1564843017, pp: 166.

Robertson, M., A. Fluck, I. Webb and B. Loechel, 2004. Classroom computer climate, teacher reflections and "reenvisioning" pedagogy in australian schools. Aus. J. Educ. Technol., 20: 351370.

Rudduck, J. and J. Flutter, 2004. How to Improve your School. 1st Edn., Continuum International Publishing Group, London, ISBN: 0826465307, pp: 189.
Savin-Baden, M., 2003. Facilitating Problem-Based Learning: Illuminating Perspectives. 1st Edn., Open University Press, Philadelphia, PA., ISBN: 0335210554, pp: 158.

Stefi-Mabry, J., M. Radlick and W. Doane, 2010. Can you hear me now? Student voice: High school and middle school students' perceptions of teachers, ICT and learning. Int. J. Educ. Dev. Inform. Commun. Technol., 6: 64-82.

Thiessen, D. and A. Cook-Sather, 2007. International Handbook of Student Experience in Elementary and Secondary School. 1st Edn., Springer, Dordrecht, ISBN: 1402033664, pp: 892. 